\title{
Fintech Development in Financial Institutions Industry: An Empirical Study on Malaysia Islamic Banks
}

\author{
Mohamad Nizam Jaafar, Amirul Afif Muhamat, Mohammad Firdaus bin \\ Mohammad Hatta, Sharifah Faigah Syed Alwi
}

To Link this Article: http://dx.doi.org/10.6007/IJARAFMS/v11-i3/10867 DOI:10.6007/IJARAFMS/v11-i3/10867

Received: 15 July 2021, Revised: 18 August 2021, Accepted: 04 September 2021

Published Online: 24 September 2021

In-Text Citation: (Jaafar et al., 2021)

To Cite this Article: Jaafar, M. N., Muhamat, A. A., Hatta, M. F. bin M., \& Alwi, S. F. S. (2021). Fintech Development in Financial Institutions Industry: An Empirical Study on Malaysia Islamic Banks. International Journal of Academic Research in Business and Social Sciences, 11(3), 487-499.

Copyright: (c) 2021 The Author(s)

Published by Human Resource Management Academic Research Society (www.hrmars.com)

This article is published under the Creative Commons Attribution (CC BY 4.0) license. Anyone may reproduce, distribute, translate and create derivative works of this article (for both commercial and non-commercial purposes), subject to full attribution to the original publication and authors. The full terms of this license may be seen at: http://creativecommons.org/licences/by/4.0/legalcode

Vol. 11, No. 3, 2021, Pg. 487 - 499

Full Terms \& Conditions of access and use can be found at http://hrmars.com/index.php/pages/detail/publication-ethics 


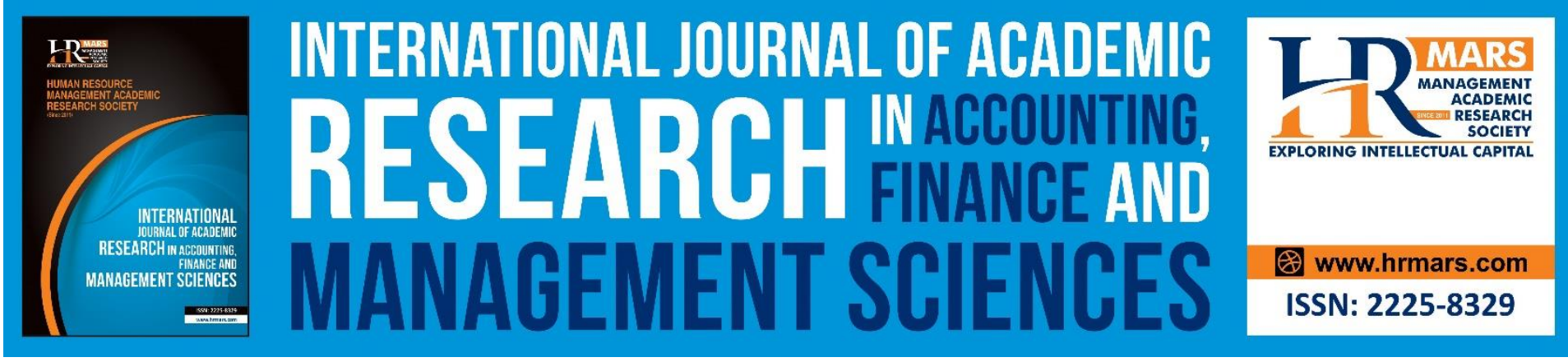

\title{
Fintech Development in Financial Institutions Industry: An Empirical Study on Malaysia Islamic Banks
}

Mohamad Nizam Jaafar

AAGBS, Universiti Teknologi MARA

Amirul Afif Muhamat

Faculty of Business and Management, UiTM Puncak Alam Campus

Mohammad Firdaus bin Mohammad Hatta

AAGBS, Universiti Teknologi MARA

\author{
Sharifah Faigah Syed Alwi \\ AAGBS, Universiti Teknologi MARA \\ Email: amirulafif@uitm.edu.my
}

\begin{abstract}
Fintech is rapidly growing, which leads to the development of new business models. Blockchain, artificial intelligence (AI), robotics, and other novel business models have become a big challenge to the banking industry in Malaysia, which includes both conventional and Islamic finance. Fintech is a promising option that can be tailored to the demands of people from different walks of life. The Fintech industry is still in its infancy, but it has enormous potential for rapid expansion. However, in order to harness such potential and make effective use of it, a conducive ecosystem is required. This study presents empirical evidence on the factors driving the emergence of Fintech in Islamic financial institutions in Malaysia, as well as those that may promote or inhibit its use in the future. A study of 311 employees from Islamic financial institutions in Malaysia was conducted and quantitative results demonstrated that favourable ecosystem is the most important issue driving Fintech growth in the Malaysia Islamic institutions followed by favorable skill set, funding, security, and stability. Nevertheless, government regulation, difficulty in transitioning to new technology, cost, and technology limits are all stumbling blocks for Fintech development in Islamic banking in Malaysia. As a result, government regulation is required to establish conducive policy for assuring the technology's long-term viability and expansion. Furthermore, the results suggest that the financial sector would be the most disrupted by Fintech. This current trend may aid decision-makers in assessing the technology's potential for use, enabling them to make strategic decisions in order to improve the firm and its
\end{abstract}


MANAGEMENT SCIENCES

Vol. 11 , No. 3, 2021, E-ISSN: 2225-8329 @ 2021 HRMARS

capabilities

Keywords: Fintech, Islamic Bank, Malaysia, Financial Service

\section{Introduction}

Since the commencement of digital revolution 4.0, there has been a renewed interest in studying the impact of Fintech on our ecosystem of economy. It's exhibited by an advancement in technologies that's diminishing the distinctions between the economic, physical, biological, and digital realms. (World Economic Forum, 2016). The financial services (FS) business is not spared to the digital revolution, which is changing how clients access financial products and services. Regardless of the fact that the banking business has gone through a series of upheavals in recent years, the ongoing penetration of technology-driven applications in practically every segment is new. A first-hand industry named "Fintech industry" formed and emerged tremendously around the industries throughout the digital revolution 4.0. Fintech is said to have had a tremendous impact on the existing banking and finance sector as it offers similar but more advanced financial services to the traditional banking and finance industry, but at cheaper rates and better pricing. Fintech will have a greater effect on Islamic banking and finance since Islamic financial institutions entail greater costs than conventional banking.

Fintech is rising at an incredible rate in Malaysia, leading to a shift in the country's financial scene. According IMF report February 2020, Malaysia Fintech products provided by top financial institutions are booming meanwhile the number of commercial bank branches and ATM are declining. Traditional Malaysian banks maintain their dominance in deposits, lending, and capital raising thereby embracing new technology and competing with or investing in new tech start-ups. As of April 2019, there were close to 200 start-ups in Malaysia in a range of Fintech areas, including payments, crowd funding, lending, and Blockchain (MDEC, 2019)

Recent Fintech research by Biancone, Secinaro \& Kamal (2019); Lacasse, Lambert \& Khan (2017); Laldin \& Furqani (2019); Todorof (2018) suggest that there is a need to study on Fintech in the context of Islamic financing, but it does not address the topic comprehensively. These studies focus on a specific aspect of Fintech, such as crowdfunding or the use of blockchain. This is substantiated by the Fintech's newness, and also the notion that its adoption in the Islamic finance industry is really in its preliminary phase. As a result, there is a major research gap in this domain. The motivation and the purpose of this research was to examine into another possible effect of Fintech and Islamic finance. This research was carried out to determine what factors can affect the Fintech industry in Islamic finance, and also the risk for disruption, due to the increased interest on Fintech by industry players and authorities. Fintech industry has largely created disruption for large banks and traditional financial institutions as it changed the system of regular practices.

\section{Literature Review}

Fintech has just gradually begun to draw the attention of Islamic finance researchers. It's significant to mention and acknowledge that gathering a corpus of Fintech literature in respect to Islamic finance will yield just a limited research paper. There has been a lot of research on Islamic Crowdfunding, however they all left out the other segment, namely Fintech. See Alonso (2015); Khan (2015); Lutfi \& Ismail (2016); Marzban, Asutay \& Boseli 
MANAGEMENT SCIENCES

Vol. 11, No. 3, 2021, E-ISSN: 2225-8329 @ 2021 HRMARS

(2014); Ng, Mirakhor \& Ibrahim (2015); Taha \& Macias (2014); Torabi (2017); Wahjono \& Marina (2017).

With the recognition that Islamic finance is still in its infancy, researchers are focusing their efforts on this specific field of Fintech, which is linked to Islamic banking and finance. Finocracy and Mirakhor (2017) explore upon how Fintech could enable risk-sharing Islamic finance become more widely adopted, with an emphasis on Blockchain technology and its potential to improve risk-sharing financing adoption. Lacasse, Lambert, and Khan (2017) conducted a study on Blockchain technology and offered their opinion on the viability of adopting Blockchain technology to ensure Shariah compliance in the Islamic finance business. The Malaysian International Islamic Financial Center (2016) produced a paper on financial technology in Islamic finance i.e an Investment Account Platform (IAP), examining how technology has become a significant enabler for future financial services and company as Islamic banking and finance has progressed. This platform will give investors direct access to new investment possibilities and enterprises, as well as Islamic banks access to a variety of creative funding sources. Lajis (2017) published two articles in which she highlighted that Fintech might also be a game changer for the Islamic finance industry, especially in the area of promoting risk-sharing Islamic finance. We identified some studies on cryptocurrencies, particularly bitcoin, and their shariah assessment (Adam, n.d.; Bergstra, 2015; Evans, 2015; Lim \& Masih, 2017; Nordin, Hassan, \& Nor, 2017; Nurhisam, 2017; Tayel \& Sganga, 2015; Zubaid, 2015; Tayel \& Sganga, 2015; Tayel \& Sganga, 2015; Tayel. These papers look at bitcoin and cryptocurrencies through the prism of shariah legitimacy. Even so, there is still a lot of disagreement among academics on this subject. We have seen some scholarly research writing related to different segments (crowdfunding, Blockchain, and Bitcoin) of Fintech with the combination of Islamic commercial law and Islamic finance (Abdullah, 2017; Hasan, 2017; Mohamed, 2017; Munshi, 2017)

\section{Methodology}

The factors impacting the growth of the Fintech markets in Islamic Bank in Malaysia, as well as their ecosystem prediction, were investigated using a quantitative approach in this study. The attitudes and perceptions of respondents about Fintech market were measured using a questionnaire.

\section{Sampling Design and Sample}

Previous research has identified two types of sampling techniques that can be employed in quantitative research: random sampling and non-random sampling (Creswell, 2013) Probability sampling is a kind of random sampling whereby each person in the population has an equitable and independent probability of being selected for the study (Sakaran et all, 2013). To confirm that the study's findings are reliable, the respondents were chosen using simple random selection from Malaysian financial institution employees. The study's participants are Islamic banking employees in various positions.

\section{Questionnaires Development}

The researcher created the instrument in this study by adapting and repurposing existing studies on Fintech uptake (Christoph, Andreas, Philipp, Jens, W. Blockchain, 2017). To achieve the study's objectives, the language and structure were changed accordingly. The questionnaire is divided into three (3) sections: a) demographics of respondents, b) factors affecting Fintech growth, and c) factors influencing Fintech growth. 
The first portion has seven (7) questions about the respondents' backgrounds, such as their age, nationality, highest level of education, department, if they are an important in the decision process, and their work experience. In the second portion, there are five (5) questions about variables impacting Fintech growth. Barriers and hurdles to Fintech adoption and startup were among these factors. Respondents must select a scale ranging from the least to the most significant elements when answering questions about factors that determine Fintech success. Twelve questions about predicting technologies are included in the final segment. The questions seek to determine, among other things, whether Fintech would have a significant impact on subjects' organizations/industries, the time frame in which the new tech are used, the industries most impacted by new tech, the advantages of Fintech, and the types of threats in the ecosystem. Some of the questions had a three-point rating system (i.e., 3- Agree, 2- Disagree, and 1- Don't know), while others had a five-point scale (5- Extremely likely, 4-Likely, 3-Neutral, 2-Unlikely, and 1-Not at all likely). The respondents used the scale to help them choose their scoring thoughts and preferences.

\section{Pilot Study}

The proposed questionnaire was assessed in a pilot study to verify if it was capable of assessing what it was designed for. Furthermore, the pilot study can assist in identifying potential issues before the questionnaire is sent to respondents in the actual survey (Pallant, 2010) In addition, before disseminating the questionnaire, the researcher solicited feedback and helpful recommendations from a Fintech expert to confirm the content validity of the questionnaire. 40 responses from Islamic financial Institutions employee were collected to assess the questionnaire's dependability. According to Hinkin (1998), the quantity of replies is sufficient for the questionnaire reliability test. In December 2019, the questionnaire was sent out, and in February 2020, the replies were received. The researcher used Cronbach's alpha to conduct a reliability test to check that the questionnaire functioning correctly. According to Sekaran (2013), a Cronbach's alpha reliability score of higher than 0.8 is regarded good. The alpha value of this pilot study is 0.88 , which is considered good. Following that, based on the evidence gained from the pilot study, adjustments in the phrasing of items were incorporated in the questionnaire form for more clarification before the official survey could be distributed.

Research was conducted by employing an online survey approach using Google Forms, as it will data collection simple. As it is immediately accessible online, this approach was utilized as that delivers a better response rate while also lessening reaction time. The extended verified questionnaire was applied online, and 500 respondents from bankers' communities' and the participants were contacted via e-mail and given a URL to respond to. The preliminary study's respondents were not included in the final study. Respondents were further reminded to submit the survey via follow-up emails. A total of 311 people responded, yielding a 62 percent response rate. Respondents come from a variety of companies, and it's possible that more than one respondent represents the same firm. From March 2020 to June 2020 , the survey was performed across a month.

\section{Results and Discussion}

The data collected from the questionnaire was subjected to descriptive analysis to determine the factors that affect Fintech overall growth and forecasts. In addition, the researcher 
MANAGEMENT SCIENCES

Vol. 11, No. 3, 2021, E-ISSN: 2225-8329 @ 2021 HRMARS

looked at the technology's possible applications. Technology players can use this information to make strategic judgments about future trends and how to advance this technology.

\section{Result and Discussion}

The findings of the study of element impacting Fintech development are presented in three (3) sections: A) respondent profile, B) variables impacting Fintech growth, and C) Fintech market forecast

Respondent Profile A total of 100 (32\%) management level and 211 (67\%) executive level made up the 311 respondents in the survey where the all respondents are Malaysian. Only $1 \%$ of them have a doctoral degree, whereas the majority (61\%) have a bachelor's degree, as seen in figure 1. Respondents with a diploma and a master's degree mainly composed approximately $19 \%$ and $20 \%$ of the respondents representing, respectively. It seems that education background play an important role in determining the involvement of respondents in Fintech because Fintech requires a combination of financial and computer science skills.

Figure 2 shows that the IT department had the highest response rate (39\%). The rest of the respondents work in a variety of sectors across organizations/companies, namely administration/human resources (25\%), loan/financing (20\%), finance (12\%), and several other departments (4 percent). As a result, competence of IT and finance is essential for anyone interested in taking part in FinTech.

The vast majority (100\%) of respondents work for Malaysian companies/organizations, with 58 percent of respondents engaged in decision-making activities at their employment. More than half of the participants (43\%) have employed for more than ten years.

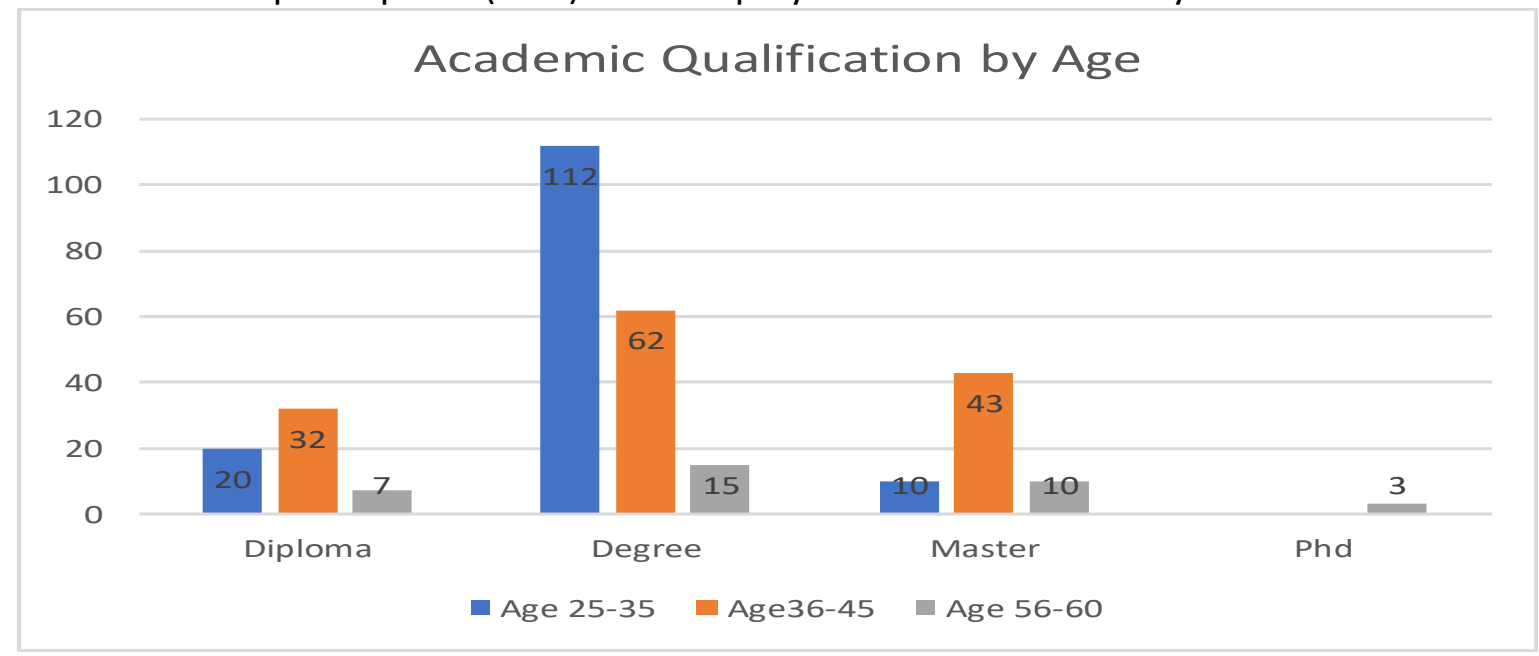

Figure 1 : Demographic profile of respondent - academic qualification by age. 


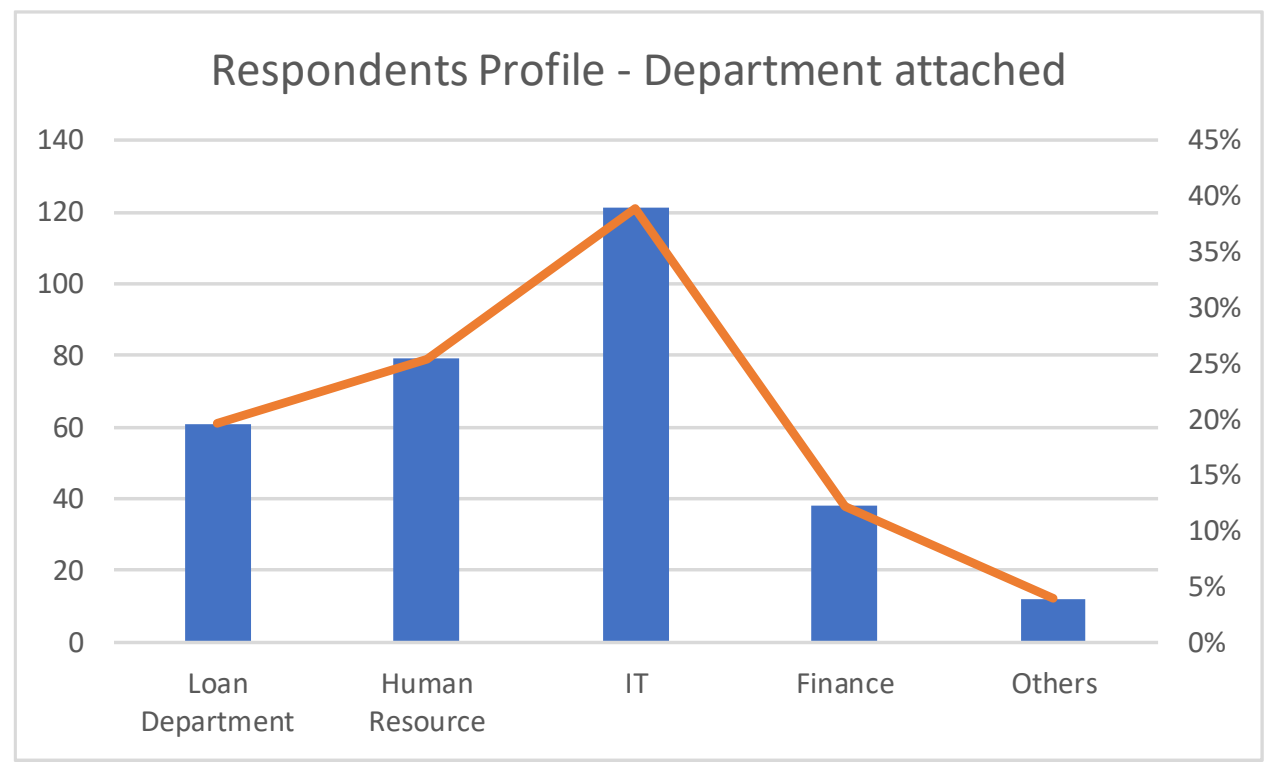

Figure 2 : Respondent department in financial institutions

\section{Industry Growth Influencing Factors}

In an assessment of the factors that determine the success of Fintech in Malaysian Islamic banks, the majority of the respondents stated that the ecosystem (30\%), skill set(20\%), funding $(21 \%)$, security $(13 \%)$ and stability (16\%) seem to be the most crucial aspects. Please refer to Figure 3

A supportive ecosystem is essential for the Fintech industry's growth, since it requires them to learn, integrate, consolidate, and create internal and external technical expertise in order to speed their innovation process. The ecosystem will help them to develop unique network relationships with Fintech startups, scale ups, tech leaders, Fintech visionaries, key industry partners, financial regulators, Fintech media and the investment community

Fintech also requires a combination of financial and computer science skills. Each of these domains is highly required in the Fintech industry. Islamic Bank required strong educational background in finance and computer science to supply the talents it requires that going to support Fintech growth.

Large incumbent enterprises, as well as other value-chain participants such as vendors and distributors, form the backbone of the ecosystem. Fintech are thus more likely to succeed in jurisdictions where the financial sector is already well-established and relatively large. Because financial institutions are a highly regulated industry with business models that rely on scale economies, Fintech requires a large upfront investment and a lengthy time to become viable. It's a business with large up-front investments and low marginal expenses later on in its life cycle. Fintech adoption occurs when there is plenty of early-stage capital and where ambitious investment rounds can be achieved in the future. It stated that $21 \%$ of the respondent stated that funding is very essential for the growth of Fintech business. 
MANAGEMENT SCIENCES

Vol. 11 , No. 3, 2021, E-ISSN: 2225-8329 @ 2021 HRMARS

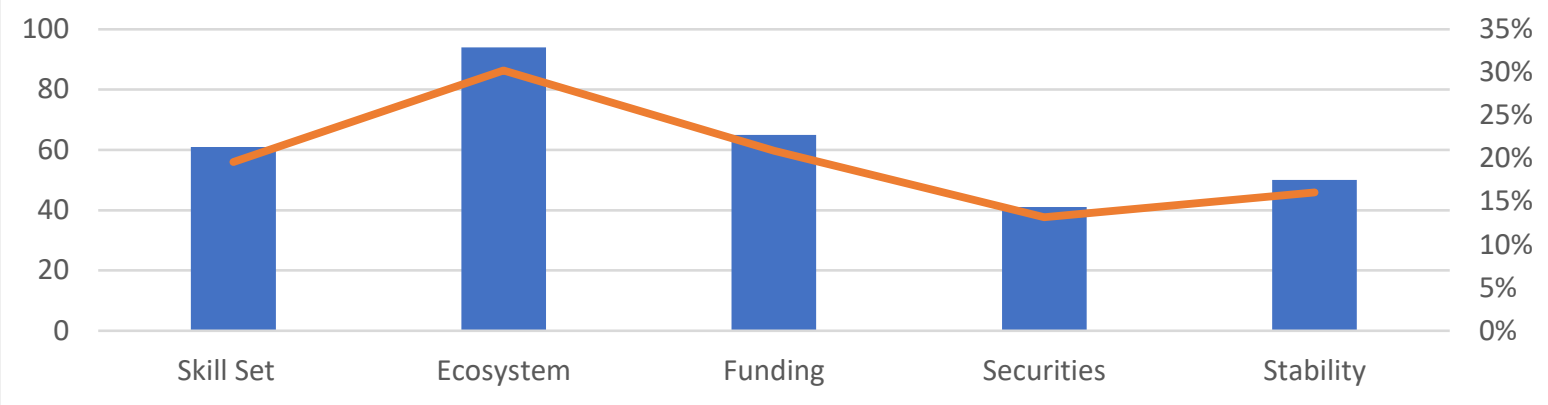

Figure 3 - Factors that influence the success of Fintech adoption

According to our findings, the number of respondents (39\%) believe that government legislation is hindering Islamic banks in Malaysia from adopting Fintech technology. Malaysia's financial system is governed by two regulatory bodies. The first is Bank Negara Malaysia (BNM), which regulates banking institutions, insurance/takaful firms, and payment and money service activities. The Securities Commission of Malaysia (SC) is the second regulatory agency, and it is a statutory entity established under the Securities Commission Act 1993 to supervise capital market activities in Malaysia. Fintech regulations are depending on the type of financial operations that a platform facilitates. Only when the financial activities are under BNM's jurisdiction is BNM liable for supervising them. The SC is participating in fintech capital market initiatives such as equity crowdfunding and peer-topeer lending. Some areas, however, are governed by both BNM and SC.

The difficulty of switching to a new technology is the second most common reason for not embracing the technology, as mentioned by around (13 percent) of the respondents. On the other hand, security is regarded as the primary reason for not using Fintect technology by $10 \%$ of respondents, whilst cost $(20 \%)$ and technological limitations $(19 \%)$ are indicated by the remaining respondents.

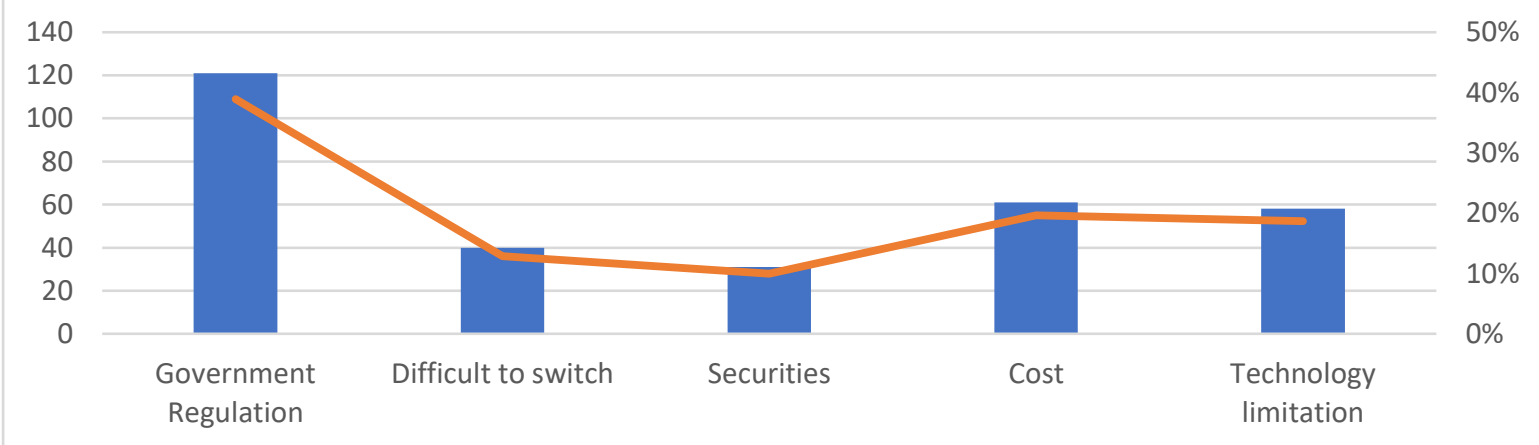

Figure $4-$ Factors that constrain adoption of Fintech

\section{Market Forecast}

Top Fintech predictions and trend of Fintech market segment revealed that the majority of the respondents (24\%) stated the Smart Chip Technology, Biometric sensor (14\%), omnichannel (7\%), Artificial Intelligent(Al) (26\%), E wallet (17\%), Block chain (10\%) and others (1\%) will dominate Fintect development in Islamic banking industry.

Smart chip ATM cards have made a substantial contribution to reducing financial losses caused by errors. It includes EMV technology, which is built within the chip. Because the code is only valid for one transaction, this method employs a one-time password for each 
MANAGEMENT SCIENCES

Vol. 11, No. 3, 2021, E-ISSN: 2225-8329 @ 2021 HRMARS

transaction, which strengthens security. Meanwhile, ATMs are seeing biometric sensors and iris scanners as two technical improvements. To identify the account owner, biometric ATMs use integrated mobile applications, fingerprint sensors, palm, and eye recognition.

Fintech financial services, on the other hand, is shifting the entire banking system from a branch-specific process to multiple digital channels such as internet, social, and mobile. It also decreases the bank's reliance on its physical locations to operate. As a result, several banks are lowering their branch count by implementing omni-channel banking.

Al has evolved into a critical component of Fintech banking services throughout time. Front office (conversational banking), middle office (fraud detection and risk management), and back office are the three key areas where artificial intelligence may help banks save money (underwriting). On the other hands, without the use of a mediator, Block chain technology allows untrustworthy parties to agree on the status of a database. A block chain might deliver certain financial services - such as payments or securitization - without the need for a bank by providing a ledger that no one manages.

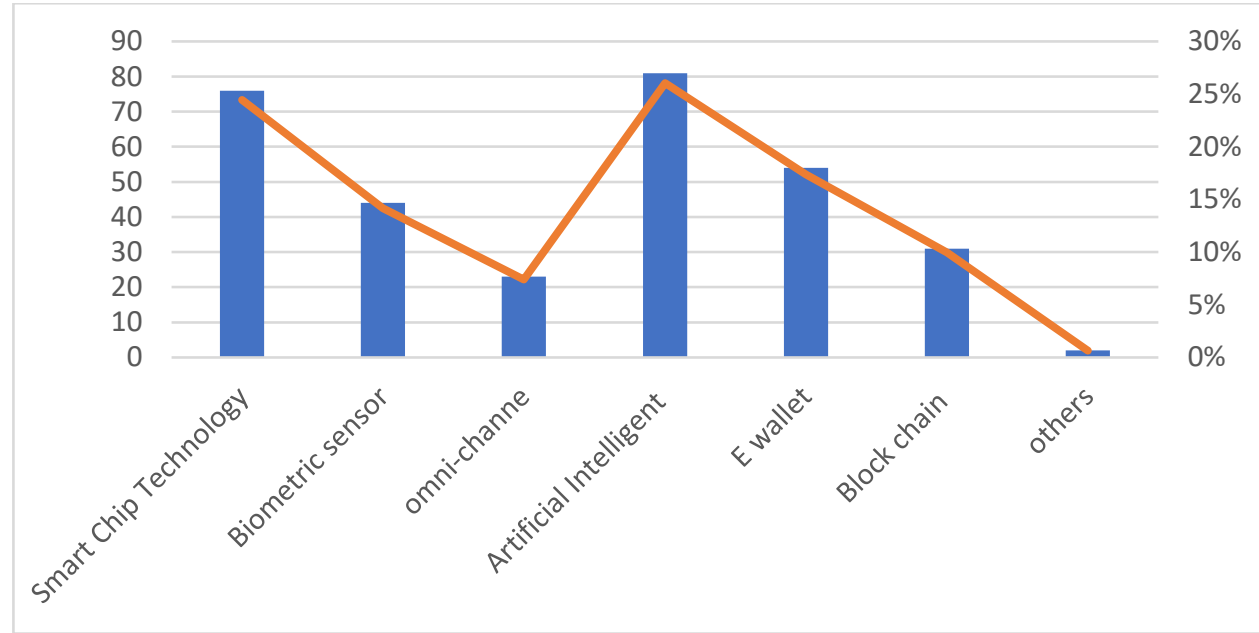

Figure 5 : Top Fintech predictions and trend of Fintech market segment

Fintech will also benefit the general public, according to 93.8 percent of respondents. Furthermore, Fintech is predicted to displace human adviser interaction for all investors, including institutional, ultra-high net worth, mass-affluent, and high net worth investors. As demonstrated in Figure 6 , respondents' perceptions of this influence are nearly same for all categories of investors.

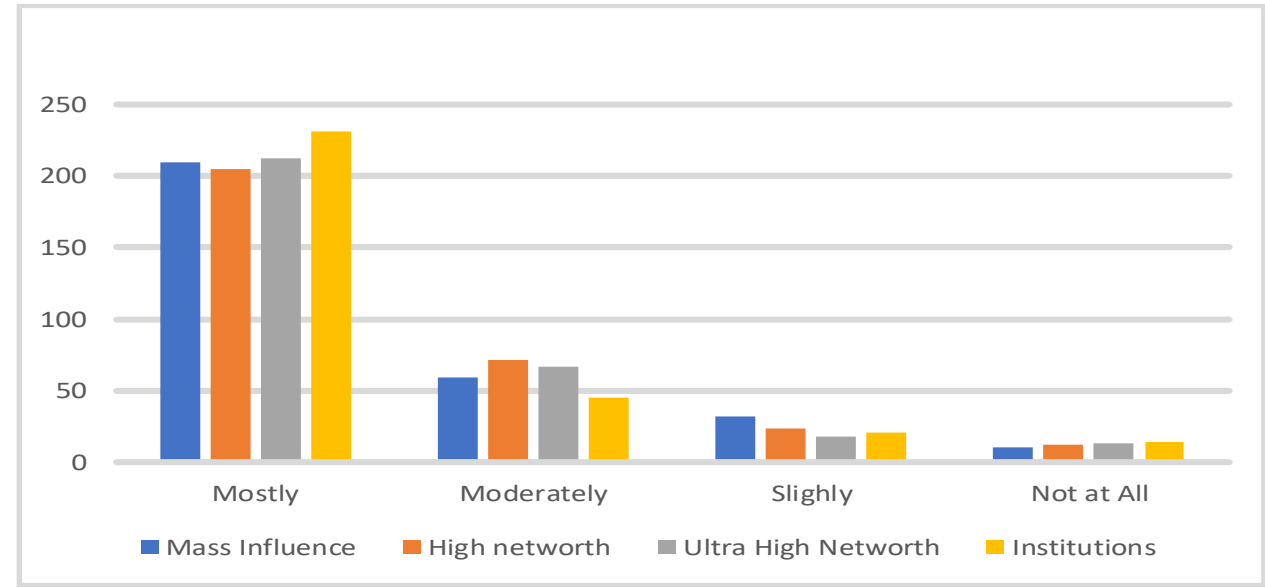

Figure 6: Impact of Fintech replacing human advisors for investors 
MANAGEMENT SCIENCES

Vol. 11, No. 3, 2021, E-ISSN: 2225-8329 @ 2021 HRMARS

The emergence of Fintech may lead to several risks in its ecosystem with $45 \%$ of respondents flaws in the automated financial advice algorithm concerns could be the biggest risk introduced from Fintech. This is followed by mass selling products $(24 \%)$, market peer-topeer lending(19\%) and crowdfunding(9\%) are also demonstrated to have impact on the financial services industry for one and five years. Figure 7 indicates that the data is remarkably similar for both times except for peer to peer lending, where in the next 5 years, it will the the major flaws of Fintech towards Islamic banks in Malaysia.

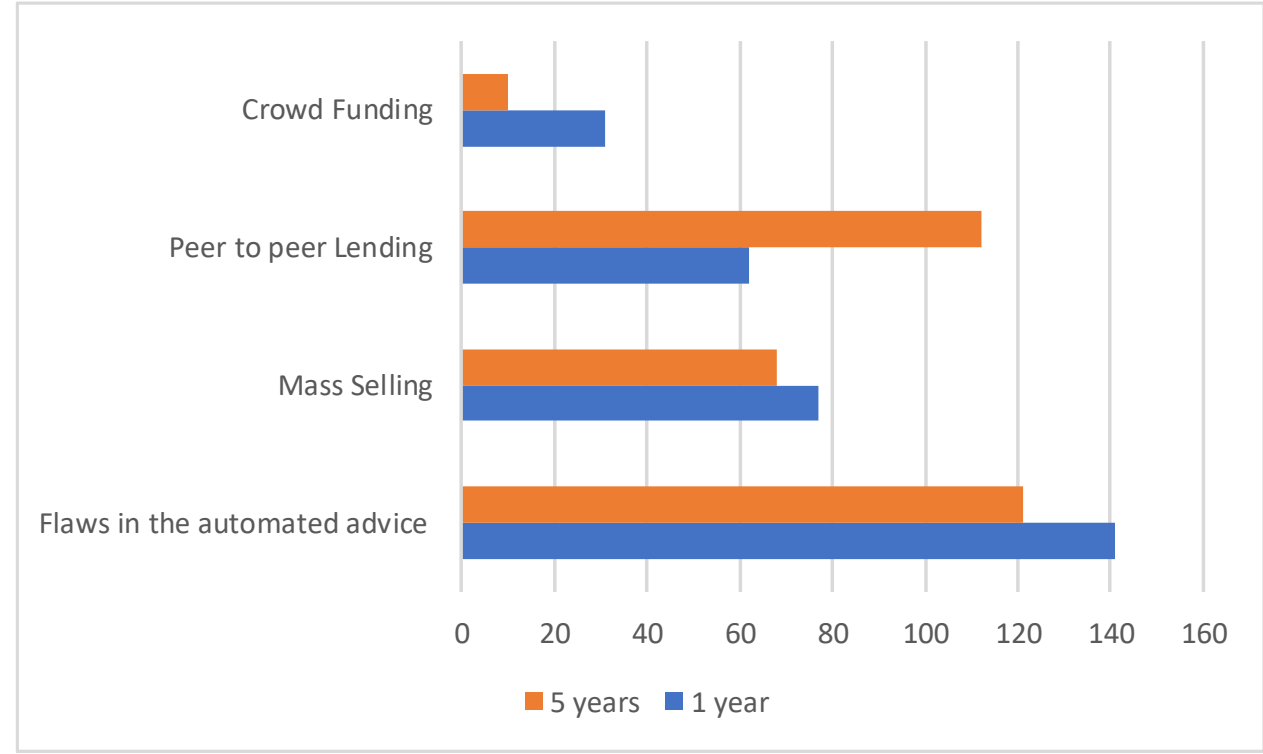

Figure 7: Impact of Fintech on technology 1 year and 5 years from now

Figure 8 shows that the same pattern of Fintech potential adoption regardless of the size of the workforce of respondents' firms. More over half of the respondents (63.3 percent) said that greater Fintech adoption in their company had a good chance of occurring. The majority of the respondents' responses ranged from moderately potential $(23.4 \%)$ to low potential $(11.7 \%)$ for Fintech adoption in their firm/industry. Only 1.6 percent of respondents do not perceive Fintech has any application potential in their firms.

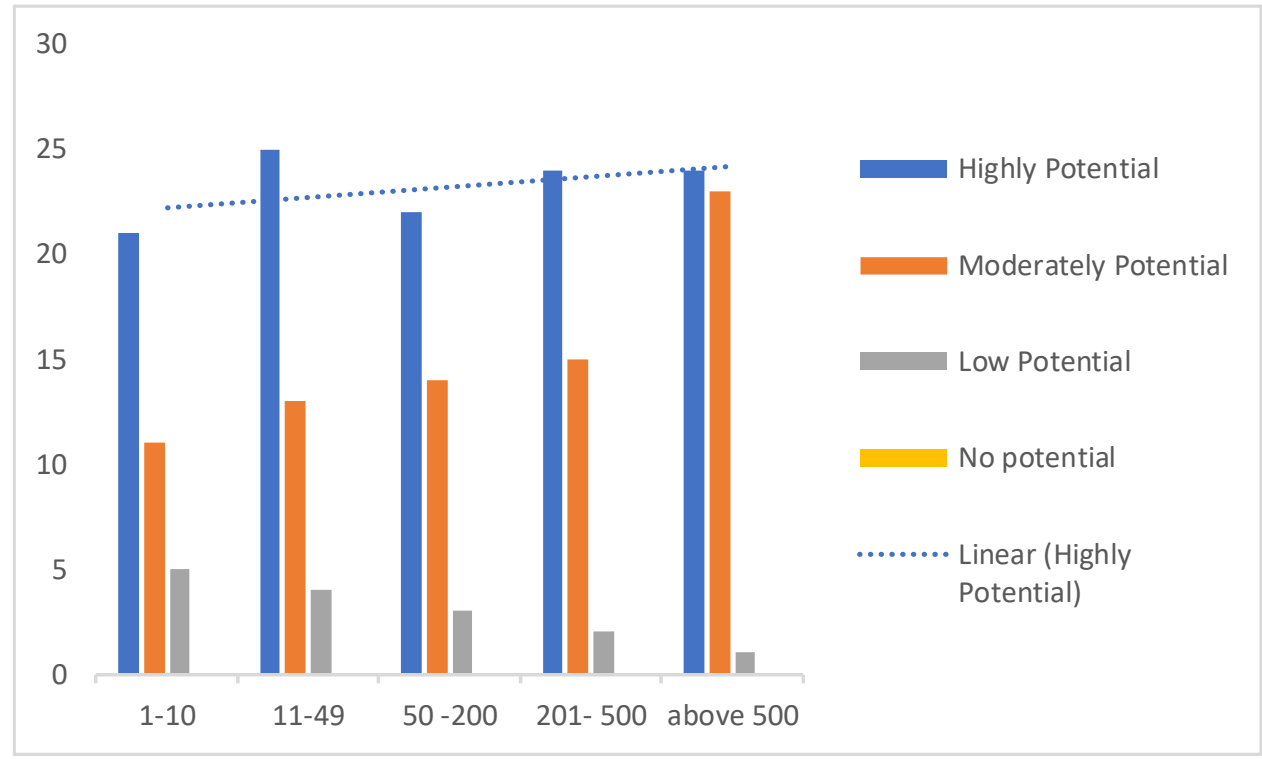

Figure 8: Potential level of Fintech technology by size of workforce 
MANAGEMENT SCIENCES

Vol. 11, No. 3, 2021, E-ISSN: 2225-8329 ๔ 2021 HRMARS

\section{Conclusion}

Fintech has established itself as a significant player in the financial sector, and the competitive advantage it provides cannot be dismissed. As a result, Islamic Financial Institutions, in notably, must react appropriately. The purpose of this paper is to present empirical insights into the factors impacting Fintech market growth in Malaysian Islamic banks, as well as the elements that may encourage or discourage future adoption. The findings demonstrate that Fintech has a significant impact on the Islamic finance business. These findings demonstrated that favourable ecosystem is the most important issue driving Fintech growth in Islamic Bank followed by favorable skill set, funding, security, and stability. Nevertheless, government regulation, difficulty in transitioning to new technology, cost, and technology limits are all stumbling blocks for Fintech development. As a result, the government, regulators, and corporations must address the issues and limitations listed if they wish to assure the success of Fintech, given how technology is now affecting our daily lives. Furthermore, in order to benefit effectively from Fintech, collaboration between Islamic Financial Institutions and Fintech businesses must be realized. Both institutions have strengths and limitations, but through collaborative efforts, each institution's weaknesses can be compensated for by the strengths of others. The growth of Fintech is a crucial opportunity for Islamic financial institutions to be very proactive; the potential influence and disruption cannot be overlooked.

\section{Acknowledgement}

Financial support from Arshard Ayub Graduate Business School, Uitm Shah Alam, Malaysia is gratefully acknowledged. Ref : 600-RMC/DANA 5/3/AAGBS (005/2020)

\section{References}

Abdullah, O. (2017). Fintech for Islamic Finance. Retrieved January 25, 2018, from Fintech for Islamic Finance website: https://isImfintech.com/

Accenture. (2016a). Blockchain Technology. Retrieved from https://www.accenture.com/t20161019T015506_w__/usen/_acnmedia/PDF-

35/Accenture-Blockchain-How-Banks-BuildingReal-Time-Global-PaymentNetwork.PDF

Accenture. (2016b). Fintech and the evolving landscape: landing points for the industry. Retrieved from https://www.finextra.com/finextradownloads/newsdocs/accenturefintech2016.pdf

Adam, M. F. (n.d.). Bitcoin: Shariah Compliant? Retrieved from http://darulfiqh.com/bitcoinshariah-compliant/

Alonso, I. M. (2015). Crowdfunding in Islamic finance and microfinance: A case study of Egypt. Access to Finance and Human Development- Essays on Zakah, Awqaf and Microfinance, 85.

Biancone, P. P., Secinaro, S., \& Kamal, M. (2019). Crowdfunding and Fintech: Business model sharia compliant. European Journal of Islamic Finance, (12). Broby, D., \& Karkkainen, T. (2016). FINTECH in Scotland: building a digital future for the financial sector

Bonneau, J., Miller, A., Clark, J., Narayanan, A., Kroll, J. A., \& Felten, E. W. SoK. (2015) Research Perspectives and Challenges for Bitcoin and Cryptocurrencies. In IEEE Symposium on Security and Privacy, 104-121.

Christoph, B., Andreas, K., Philipp, R. and Jens, W. (2017). Blockchain in the energy transition. A survey among decision-makers in the German energy industry. 
MANAGEMENT SCIENCES

Vol. 11, No. 3, 2021, E-ISSN: 2225-8329 ๔ 2021 HRMARS

Delmolino, K., Arnett, M., Kosba, A., Miller, A., \& Shi, E. (2016) Step by Step Towards Creating a Safe Smart Contract: Lessons and Insights from a Cryptocurrency Lab. In International Conference on Financial Cryptography and Data Security, 79-94.

Garay, J., Kiayias, A., \& Leonardos, N. (2015). The Bitcoin Backbone Protocol: Analysis and Applications. In: Advances in Cryptology - EUROCRYPT, 281-310.

Giungato, P., Rana, R., Angela, T., \& Caterina, T. (2017) Current trends in sustainability of bitcoins and related blockchain technology. Sustainability 9 (12) 1-11

Hasan, S. B. M. (2017). Islamic Fintech - A Threat for Islamic Banks or an Opportunity? Retrieved January 25, 2018, from Ethis Crowd Blog website: https://www.ethiscrowd.com/blog/islamicfintech-and-islamic-banks/

Hinkin, T. R. (1998) A Brief Tutorial on the Development of Measures for Use in Survey Questionnaires. Organizational Research Methods, 104-121

Kosba, A. Miller, A., Shi, E., Wen, Z., \& Papamanthou, C. H. (2016). The Blockchain Model of Cryptography and Privacy-Preserving Smart Contracts, In IEEE Symposium on Security and Privacy (SP), 839-858.

Kraft, D. (2016) Difficulty control for blockchain-based consensus systems. Peer-to-Peer Networking and Applications 9 (2) 397-413.

Lewenberg, Y., Sompolinsky, Y., \& Zohar. (2015) A. Inclusive Block Chain Protocols. Lecture Notes Computer Sciences (including Subser. Lect. Notes Artif. Intell. Lect. Notes Bioinformatics), 528-557.

Pallant, J. SPSS (2010), Survival manual: A step by step guide to data analysis using SPSS (4th Ed.). Buckingham: Open University Press, 2010.

Reyna, A. Martín, C., Chen, J., Soler, E., \& Díaz, M. (2018) On blockchain and its integration with IoT. Challenges and opportunities, Future Generation Computer System 88 (2018) 173-190.

Sharples, M., \& Domingue, J. (2016) The Blockchain and Kudos: A Distributed System for Educational Record, Reputation and Reward. In Adaptive and Adaptable Learning,490496. [7]

Stejskal, J., Hajek, P., \& Prokop, V. (2018) Collaboration and innovation models in information and communication crea-tive industries - the case of Germany, Journal of Information and Communication Technology, vol. 17, no. 2, 2018, pp. 191-208

Taha, T., \& Macias, I. (2014). Crowdfunding and Islamic Finance: A Good Match? In Social Impact Finance (pp. 113-125). Springer.

Tayel, M. M. I., \& Sganga, C. (2015). Can bitcoin be self-regulatory legal tender?: a comparative analysis of united states, european union and islamic legal systems. The White House. (2016). Big Data: A Report on Algorithmic Systems, Opportunity, and Civil Rights. Washington.

Torabi, O. (2017). Using reputation (fame) to reduce information asymmetry in Islamic risksharing crowdfunding models: a game theory approach. Todorof, M. (2018). Shariahcompliant fintech in the banking industry. ERA Forum, 19, 1-17. Springer.

Turner, V., Gantz, J. F., Reinsel, D., \& Minton, S. (2014). The digital universe of opportunities: Rich data and the increasing value of the internet of things. IDC Analyze the Future, 5.

Tschorsch, F. B., \& Beyond. (2016) A Technical Survey on Decentralized Digital Currencies. IEEE Communication Surveys and Tutorials 18 (3)2084-2123.

Woodside, J. M., Giberson, F. K. A. Jr, W., \& Woodside, J. M. (2017) Blockchain Technology Adoption Status and Strategies. Journal of International Technology and Information Management 26 (2) 65-93. 
INTERNATIONAL JOURNAL OF ACADEMIC RESEARCH IN ACCOUNTING, FINANCE AND MANAGEMENT SCIENCES

Vol. 11 , No. 3, 2021, E-ISSN: 2225-8329 @ 2021 HRMARS

World Economic Forum. (2016). The future of financial infrastructure: An ambitious look at how blockchain can reshape financial services (p. 130). Retrieved from http://weforum.org/reports/the-future-offinancial-infrastructure-an-ambitious-lookat-how-blockchain-canreshape-financial-services 